УДК 664.661:664.537

DOI https://doi.org/10.32851/tnv-tech.2021.6.13

\title{
ПОРІВНЯЛЬНА ОЦІНКА СИРОВИНИ ДЛЯ ВИРОБНИЦТВА БЕЗГЛЮТЕНОВОГО ПРІСНОГО ТІСТА
}

\author{
Дзюндзя О.В. - кандидат технічних наук, \\ доцент кафедри інженерії харчового виробництва \\ Херсонського державного аграрно-економічного університету \\ ORCID ID: 0000-0002-1996-7065 \\ Scopus-Author ID: 57200823212 \\ Руденко Є.О. - студентка магістратури \\ біолого-технологічного фракультету \\ Херсонського державного аграрно-економічного університету \\ ORCID ID: 0000-0001-9077-420X \\ Куришко А.П. - студентка бакалаврату \\ біолого-технологічного фракультету \\ Херсонського державного аграрно-економічного університету \\ ORCID ID: 0000-0002-3150-344X
}

Враховуючи темп життя сучасної людини та збільшення хвороб, які безпосередньо пов'язані з харчуванням, виникає необхідність перегляду раціонів та створення продуктів спеціального призначення. Відповідно до даних Всесвітньої організації охорони здоров'я щзороку спостерігається збільшення хворих на целіакію, щзо викликана алергічною реакиією на глютен. Це хронічне довічне імунозапальне захворювання, через щьо хворим необхідно пожиттєво дотримуватися безглютенової дієти. Глютен міститься в білку злакових культур, таких як пшениця, овес, жито, ячмінь. Отже, виникає необхідність пошуку перспективних аналогів для виробничтва борошняних страв $і$ виробів.

Враховуючи попит на напівфабрикати борочняних кулінарних виробів, таких як вареники, пельмені, хінкалі тощзо, у статті розглянуто можливість виробництва прісного безглютенового тіста для них. 3 огляду на різноманітні фактори предметом дослідження було обрано рисове та кукурудзяне борошно. Отримані дані свідчать, щчо водопоглинальна здатність борочна кукурудзяного і рисового наближена до контрольного зразка пиеничного борошна, тому використання цієї сировини не повинно сильно впливати на структурно-механічні властивості тіста.

Згідно з проведеними дослідженнями кінематичної в'язкості тіста визначено, що меншу в'язкість має тісто з рисового борошна, порівняно з кукурудзяним, а ие призводить до необхідності збільшення частки изього виду борошна в рецептурі. Проведені експериментальні проробки з виробництва прісного тіста з борошна риса $і$ кукурудзи у різних пропорціях доводять цее твердження. Встановлено, щуо оптимальним є таке співвідношення борошна рисового до кукурудзяного: 75:25. За органолептичними показниками розроблена рецептура прісного тіста не поступалася контрольному зразку з пшеничного борошна. 3 огляду на иее вважаємо, шо зазначене дослідження має вагоме значення для хворих на целіакію і дає можливість розиирити щзоденний раціон різноманітними стравами.

Ключові слова: целіакія, прісне тісто, напівфабрикат, безглютенове борошно, глютен.

Dzyundzya O.V., Rudenko Ye.O., Kuryshco A.P. Comparative evaluation of raw materials for the production of gluten-free dough

Given the pace of life of modern man and the increase in diseases that are directly related to nutrition, there is a need to review diets and create special products. According to the WHO, every year there is an increase in patients with celiac disease, which is caused by an allergic reaction to gluten. This disease is defined as chronic, lifelong immunoinflammatory, as a consequence, patients need to follow a vital gluten-free diet. Gluten is found in the protein of cereals such as wheat, oats, rye, barley. Accordingly, there is a need to find promising analogues for the production of flour dishes and products. 
Given the demand for semi-finished flour products, such as dumplings, dumplings, khinkali, etc., the article considers the possibility of producing fresh gluten-free dough for them. Rice and corn flour were selected taking into account various factors and factors. The obtained data indicate that the water absorption capacity of corn and rice flour is close to the control sample of wheat flour, so the use of this raw material should not greatly affect the structural and mechanical properties of the dough.

Studies of the kinematic viscosity of the dough have shown that the dough of rice flour has a lower viscosity compared to corn, which leads to the need to increase the proportion of this type of flour in the recipe. Experimental studies on the production of fresh dough from rice flour and corn in different proportions confirm this statement. It was found that the optimal ratio of rice flour to corn-75:25. According to organoleptic parameters, the developed recipe of fresh dough was not inferior to the control sample of wheat flour. In view of this, we believe that this development is important for patients with celiac disease and makes it possible to expand the daily diet with a variety of dishes.

Key words: tsiaklia, fresh dough, semi-finished product, gluten-free flour, gluten.

Вступ. Незважаючи на значні напрацювання в харчовій галузі з виробництва продукції спеціального призначення [1-13], невирішеною залишається проблема виробництва продукції для осіб, що страждають на різноманітні специфічні захворювання, зокрема на целіакію. Перспективним 3 точки зору виробників $\epsilon$ виробництво безглютенових борошняних виробів, зокрема $з$ прісного тіста, що дозволить розширити асортимент страв для хворих. Використання нетрадиційної борошняної сировини дасть змогу створити новий якісний продукт, що не міститиме природний алерген - глютен.

Постановка проблеми. Враховуючи сучасні тенденції, дедалі більше споживачів у своєму раціоні використовують напівфабрикати різного ступеня готовності промислового виробництва. Великий попит має заморожена продукція: млинці, вареники, пельмені, равіолі, піци тощо. Однак, враховуючи специфічні потреби певних груп людей, виникає необхідність створення нових продуктів, що будуть відповідати критеріям раціонального харчування та задовольняти споживчі вимоги. Зважаючи на те, що целіакія - це генетичне захворювання, яке вимагає пожиттєвого дотримання аглютенової дієти, створення продукції спеціального призначення $є$ актуальним.

Метою статті $\epsilon$ дослідження оптимального співвідношення рецептурних компонентів для виробництва безглютенових пельменів із використанням кукурудзяного, рисового та амарантового борошна, що відповідатиме вимогам раціонального харчування.

Відповідно до мети слід виконати такі завдання:

- визначити реологічні показники тіста;

- визначити оптимальне співвідношення рецептурних компонентів прісного тіста для аглютенових борошняних кулінарних виробів.

Аналіз останніх досліджень і публікацій. Целіакія - це захворювання, спричинене несприйняттям організмом глютена, через що хворим доводиться впродовж життя бути на безглютеновій дієті, тобто вживати продукцію, яка містить не більше 200 мг глютена на 1 кг продукту в перерахунку на сухий зразок.

Виявлено, що офіційної статистики хворих на целіакію в Україні немає, однак під час аналізу інформаційних джерел було з'ясовано, що частка продажу безглютенової продукції в світі щороку збільшується на 10,4\% [1; 2], що підтверджує необхідність виготовлення такої продукції.

3'ясовано, що основними інгредієнтами для виробництва безглютенових продуктів $€[3-8]$ : 
- різновиди борошна з високим вмістом крохмальних і некрохмальних полісахаридів (рисове борошно, кукурудзяне борошно, борошно вівсяне, борошно 3 псевдозернових (амаранта, гречки) та круп'яних культур (проса), борошно з сорго, лляне борошно, борошно з арахісу, люпинове борошно тощо);

- високобілкові інгредієнти (соєві ізоляти та концентрати, ізоляти білків гороху, люпину, казеїнати, концентрати сироваткових білків тощо);

- гідроколоїди (ксантан, гуарова камедь, різні види натуральних і модифікованих крохмалів (картопляний, кукурудзяний, рисовий, сорго тощо), мікробіальні полісахариди);

- емульгатори, розпушувачі, смакові інгредієнти (меланж, лецитин, харчова сода, сіль, цукор, ароматизатори, барвники, мінеральні добавки).

Резюмуючи результати низки останніх досліджень науковців з усього світу, було виявлено необхідність покращення харчової якості безглютенових продуктів на основі злакових культур, що характеризуються відмінним профілем поживних речовин. Таким чином, дедалі більше дослідження зосереджуються на використанні таких злакових культур в рецептурі високоякісних, здорових продуктів без глютена, зокрема хліба, макаронних виробів та іншої борошновмісної продукції. Однак комерціалізація цих продуктів все ще досить обмежена. Наявність смачних продуктів без глютена, що містять псевдозлаки, стане значним прогресом у забезпеченні адекватного споживання поживних речовин у пацієнтів із целіакією [9-12].

Виклад основного матеріалу. Найбільш поширеною безглютеновою сировиною $є$ кукурудзяне і рисове борошно. Тому з метою створення оптимального рецептурного співвідношення основної борошняної сировини було розглянуто головні технологічні особливості.

Кукурудзяне борошно, залежно від сорту, містить до 10\% білків та 5\% жирів, до $70 \%$ крохмалю. Рисове борошно різних виробників містить $70 \%$ вуглеводів, із яких крохмалю - 55\%, білків - до $10 \%$, жирів - близько $1 \%$.

Завдяки значному вмісту вуглеводів ці види борошна мають гарні цукроутворювальні властивості та клейстеризацію. Варто зауважити, що їх енергетична цінність нижча за інші безглютенові види борошна [13].

Враховуючи, що в'язкість тіста через значну кількість крохмалю може бути вищою за класичну рецептуру, необхідно встановити оптимальне співвідношення рецептурних компонентів. Тому було проведено низку експериментальних досліджень основних структурно-механічних характеристик, від яких залежить формування прісного тіста з безглютенового борошна. Відомо, що вироби з безглютенової сировини характеризуються низьким вмістом вологи, внаслідок чого щільність і пружність збільшуються, а пластичні властивості змінюються. Зі збільшенням пластичності тісто втрачає пружність, стає менш міцним, більш липким. Тому під час розробки нової продукції необхідно враховувати ці особливості.

Водопоглинальна здатність впливає на в'язкість досліджуваних зразків і вологість тіста, вихід та якість готових виробів. Водопоглинальна здатність визначається під час замісу тіста за температури $32^{\circ} \mathrm{C}$. Динамічна в'язкість визначається за температури $20^{\circ} \mathrm{C}$. На рис. 1 зображено результати дослідження водопоглинальної здатності різних видів борошна.

Враховуючи отримані результати, можемо стверджувати, що за показниками водопоглинальна здатність борошна кукурудзяного і рисового найбільш наближена до контрольного зразка пшеничного борошна, тому використання цієї сировини не повинно сильно впливати на структурно-механічні властивості тіста. 


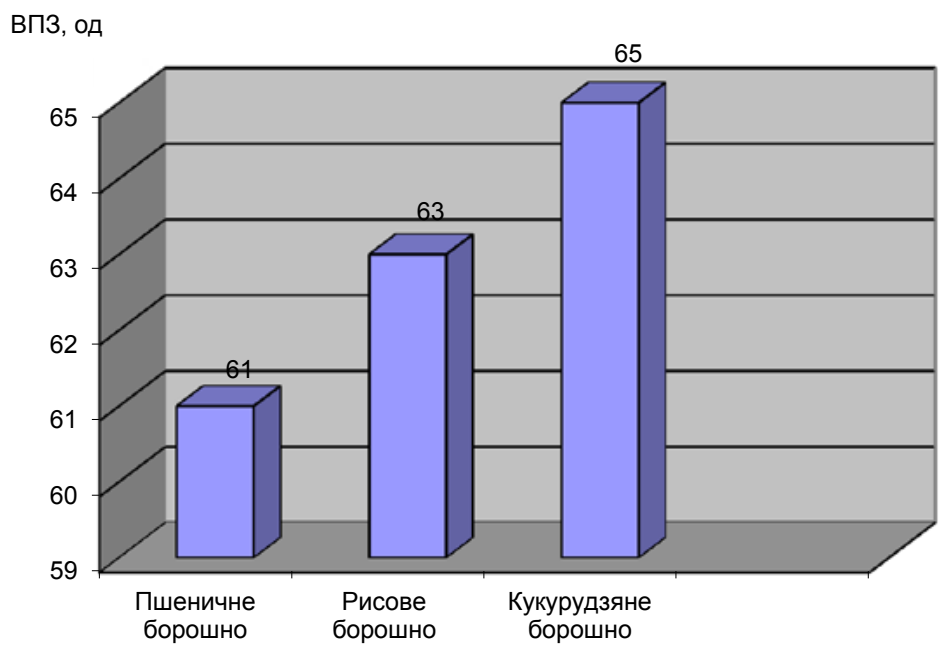

Рис. 1. Водопоглинальна здатність різних видів борошна

Зважаючи на технологічні особливості борошна, важливим є дослідження кінематичної в’язкості тіста, що безпосередньо впливає на якість готових виробів. Результати дослідження в'язкості наведено на рис. 2.

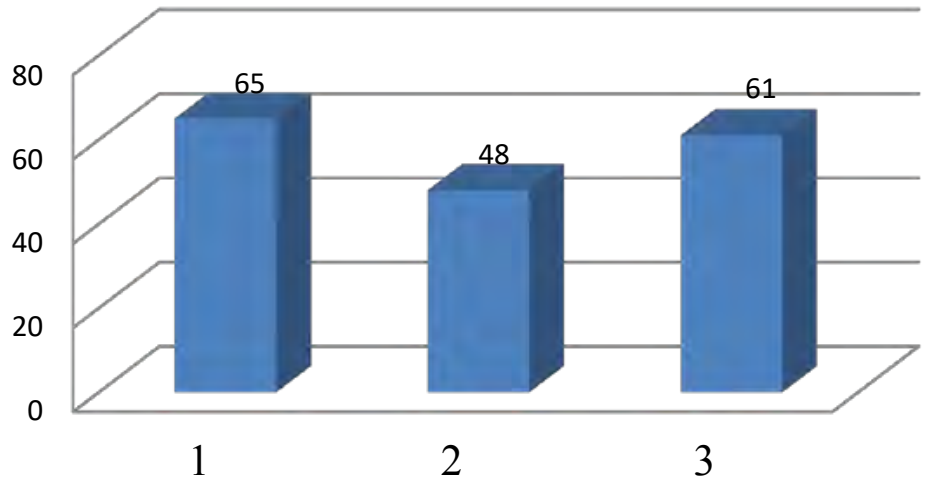

Рис. 2. Кінематична в'язкість тіста, де

1 - пшеничне борочно, 2 - рисове борошно, 3 - кукурудзяне борошно

Згідно з рис. 2 результати дослідження кінематичної в’язкості показують, що меншу в'язкість має тісто з рисового борошна, що веде до необхідності збільшення частки цього виду борошна в рецептурі. Тому для отримання визначених властивостей доцільно комбінувати рисове борошно з кукурудзяним, яке має підвищену кінематичну в'язкість, та іншими видами, що мають більш слабку кінематичну в'язкість. Адже безпосередній вплив на якість готових виробів мають основні борошняні компоненти, зокрема борошно, що використовується в рецептурі. Саме пропорційні співвідношення різних видів аглютенової сировини визначають органолептичні (табл. 1) та фізико-хімічні властивості готового виробу, тобто вареного прісного тіста. 
Таблиця 1

Органолептична оцінка безглютенового тіста

\begin{tabular}{|c|c|c|c|}
\hline \multirow[b]{2}{*}{ Показники } & \multicolumn{3}{|c|}{ Співвідношення рисового і кукурудзяного борошна, \% } \\
\hline & $\begin{array}{c}\text { Дослід } 1 \\
\mathbf{5 0 : 5 0}\end{array}$ & $\begin{array}{c}\text { Дослід } 2 \\
\text { 25:75 }\end{array}$ & $\begin{array}{c}\text { Дослід } 3 \\
75: 25\end{array}$ \\
\hline Зовнішній вигляд & \multicolumn{3}{|c|}{ Поверхня гладка, без розривів, на розрізі тісто слоїться } \\
\hline Консистенція & $\begin{array}{l}\text { Однорідна маса без } \\
\text { грудочок та слідів } \\
\text { непромісу }\end{array}$ & $\begin{array}{l}\text { Однорідна маса без } \\
\text { грудочок та слідів } \\
\text { непромісу }\end{array}$ & $\begin{array}{l}\text { Однорідна, } \\
\text { еластична маса без } \\
\text { грудочок та слідів } \\
\text { непромісу }\end{array}$ \\
\hline Колір & \begin{tabular}{|l} 
Світлий, \\
жовтуватий
\end{tabular} & Жовтуватий & Білий \\
\hline $\begin{array}{l}\text { Стан тіста після } \\
\text { варіння }\end{array}$ & $\begin{array}{l}\text { Гладка поверхня, } \\
\text { без тріщин та } \\
\text { розривів, щільне }\end{array}$ & $\begin{array}{l}\text { Гладка поверхня, } \\
\text { без тріщин та } \\
\text { розривів, щільне } \\
3 \text { незначними } \\
\text { рельєфами }\end{array}$ & $\begin{array}{l}\text { Гладка поверхня, } \\
\text { без тріщин } \\
\text { та розривів, } \\
\text { рівномірно щільне }\end{array}$ \\
\hline Запах & \multicolumn{3}{|c|}{ Властивий прісному тісту, без сторонніх запахів } \\
\hline Смак & $\begin{array}{l}\text { Властивий } \\
\text { прісному тісту, } \\
\text { без сторонніх } \\
\text { присмаків, } \\
\text { відчутний присмак } \\
\text { кукурудзяного } \\
\text { борошна }\end{array}$ & $\begin{array}{l}\text { Властивий } \\
\text { прісному тісту, } \\
\text { виражений смак } \\
\text { кукурудзяного } \\
\text { борошна }\end{array}$ & $\begin{array}{l}\text { Властивий } \\
\text { прісному тісту, без } \\
\text { сторонніх смаків }\end{array}$ \\
\hline
\end{tabular}

В результаті експериментальних досліджень було з'ясовано, що найбільш оптимальним є співвідношення рисового і кукурудзяного видів борошна у пропорції 75:25. Ці зразки мали гарну еластичність, тісто добре замішувалося, після варіння спостерігалося збереження форми, варене тісто не злипалося. Однак за умови збільшення частки кукурудзяного борошна щільність виробів зростала.

Зауважимо, що безглютенове прісне тісто має кращі показники, ніж класичне 3 пшеничного борошна (табл. 2).

Таблиця 2

\section{Порівняльна характеристика прісного тіста}

\begin{tabular}{|l|c|c|c|c|}
\hline \multirow{2}{*}{ Показник } & \multicolumn{3}{|c|}{ Пшеничне тісто (контроль) } & \multicolumn{2}{|c|}{$\begin{array}{c}\text { Безглютенове тісто, } \\
\text { співвідношення рисового } \\
\text { i кукурудзяного борошна } \\
\end{array}$} & \multicolumn{2}{|c|}{$\mathbf{7 5 : 2 5}$} \\
\hline & До варіння & Після варіння & До варіння & Після варіння \\
\hline Вологість, \% & $37 \pm 1$ & $54 \pm 1$ & $43 \pm 1$ & $67 \pm 1$ \\
\hline Маса, г & $100 \pm 0,5$ & $130 \pm 1$ & $100 \pm 0,5$ & $140 \pm 1$ \\
\hline
\end{tabular}

Отже, відповідно до даних табл. 2, спостерігаємо підвищення вологості тістових заготовок та збільшення ваги вареного дослідного зразка, порівняно з контролем, тобто привар на 7,7\% більший. 
Висновки і пропозиції. Відповідно до поставленої мети було:

- визначено перспективні види борошна для виробництва аглютенового прісного тіста;

- 3'ясовано, що оптимальним для виробництва прісного безглютенового тіста $\epsilon$ співвідношення рисового та кукурудзяного борошна, що становить 75:25.

Отже, результати проведених досліджень довели можливість приготування прісного безглютенового тіста, що є напівфабрикатом для низки борошняних кулінарних виробів, таких як вареники, пельмені, хінкалі тощо. Ця розробка має важливе значення для хворих на целіакію і дає змогу розширити їх щоденний раціон різноманітними стравами. Перспективою подальших досліджень є більш глибоке вивчення властивостей тіста і приготування з нього кулінарних страв.

\section{СПИСОК ВИКОРИСТАНОЇ ЛІТЕРАТУРИ:}

1. Market and Markets Gluten-Free Products Market by Type (Bakery Products, Pizzas \& Pastas, Cereals \& Snacks, Savories, and Others), Source (Oilseeds \& Pulses, Rice \& Corn, Dairy \& Meat Products, and Other Crops), by Region-Global Trends \& Forecast to 2020. URL: https://www.marketsandmarkets.com/Market-Reports/glutenfree-products-market-738.html (accessed on: 31 July 2018).

2. Melini, V., Melini, F. Gluten-free diet: Gaps and needs for a healthier diet. Nutrients. 2019. No. 11 (1). P. 170.

3. Ukrainets, A. et al. A study of the effect of enriched whey powder on the quality of a special purpose bread. Eastern-European Journal of Enterprise Technologies. 2016. Vol. 2. Issue 11 (80). P. 32-41. DOI: 10.15587/1729-4061.2016.65778/.

4. Пахомська О.В. Науковий підхід до створення хлібобулочних виробів функціонального призначення. Наукові пращі Національного університету харчових технологій. 2019. № 2. С. 276-283.

5. Дробот В.І., Приходько Ю.С., Бережна Г.О. Борошно сорго у технології безглютенового хліба. Наукові праці Наџіонального університету харчових технолоzій. 2019. № 1. С. 208-214.

6. Медвідь І.М., Шидловська О.Б., Доценко В.Ф. Перспективи використання амілолітичних ферментів у технології рисового хліба для хворих на целіакію : збірник тез доповідей VI Міжнародної науково-технічної конференції молодих учених та студентів «Актуальні задачі сучасних технологій». 2017. № 3. С. 154.

7. Дробот В.І., Михонік Л.А., Грищенко А.М. Вплив структуроутворювачів на якість безглютенового хліба із суміші рисового та кукурудзяного борошна. Наукові праці Національного університету харчових технологій. 2017. № 6. С. 169-175.

8. Христенко А.С. Хлібобулочні вироби з пониженим вмістом алергенів. Bicник студентського наукового товариства "ВАТРА» Вінницького торговельноекономічного інституту КНТЕУ. 2020. Вип. 98. С. 137-145.

9. Alvarez-Jubete, L., Arendt, E.K., Gallagher, E. Nutritive value of pseudocereals and their increasing use as functional gluten-free ingredients. Trends in Food Science \& Technology. 2010. Vol. 21. Issue 2. P. 106-113.

10. Xu, J., Zhang, Y., Wang, W., Li, Y. Advanced properties of gluten-free cookies, cakes, and crackers: A review. Trends in Food Science \& Technology. 2020. Vol. 103. P. 200-213.

11. Rai, S., Kaur, A., Chopra, C.S. Gluten-free products for celiac susceptible people. Frontiers in nutrition. 2018. № 5. P. 116.

12. Martínez-Villaluenga, C., Peñas, E., Hernández-Ledesma, B. Pseudocereal grains: Nutritional value, health benefits and current applications for the development of gluten-free foods. Food and Chemical Toxicology. 2020. Vol. 137. P. 111-178. DOI: $10.1016 /$ j.fct.2020.111178.

13. Дзюндзя О.В., Звагольська К.М. Аналіз нетрадиційної борошняної сировини для виробництва хлібобулочних виробів. Таврійський науковий вісник. Серія «Технічні науки». 2021. № 1. C. 22-29. DOI: 10.32851/tnv-tech.2021.1.4. 


\section{REFERENCES:}

1. Market and Markets Gluten-Free Products Market by Type (Bakery Products, Pizzas \& Pastas, Cereals \& Snacks, Savories, and Others), Source (Oilseeds \& Pulses, Rice \& Corn, Dairy \& Meat Products, and Other Crops), by Region-Global Trends \& Forecast to 2020. Available online: https://www.marketsandmarkets.com/Market-Reports/gluten-free-products-market-738.html (accessed on: 31 July 2018). [in English]

2. Melini, V., Melini, F. (2019) Gluten-free diet: Gaps and needs for a healthier diet. Nutrients. Vol. 11 (1). pp. 170. [in Italian]

3. Ukrainets A. et al. (2016) A study of the effect of enriched whey powder on the quality of a special purpose bread. Eastern-European Journal of Enterprise Technologies. Vol. 2. Issue 11 (80). pp. 32-41. DOI: 10.15587/1729-4061.2016.65778. [in Ukrainian]

4. Pakhoms'ka, O.V. (2019) Naukovyy pidkhid do stvorennya khlibobulochnykh vyrobiv funktsional'noho pryznachennya [Scientific approach to the creation of functional bakery products] Naukovi pratsi Natsional'noho universytetu kharchovykh tekhnolohiy. Vol. 25. No 2, pp. 276-283. [in Ukrainian]

5. Drobot, V.I., Prykhod'ko, Yu.C., Berezhna, H.O. (2019) Boroshno sorho u tekhnolohiyi bezhlyutenovoho khliba [Sorghum flour in the technology of gluten-free bread]. Naukovi pratsi Natsional'noho universytetu kharchovykh tekhnolohiy. Vol. 25. No. 1. pp. 208-214. [in Ukrainian]

6. Medvid', I.M., Shydlovs'ka, O.B., Dotsenko, V.F. (2017) Perspektyvy vykorystannya amilolitychnykh fermentiv u tekhnolohiyi rysovoho khliba dlya khvorykh na tseliakiyu [Prospects for the use of amylolytic enzymes in rice bread technology for patients with celiac disease] : zbirnyk tez dopovidey VI Mizhnarodnoyi naukovo-tekhnichnoyi konferentsiyi molodykh uchenykh ta studentiv "Aktual'ni zadachi suchasnykh tekhnolohiy". No. 3. pp. 154-154. [in Ukrainian]

7. Drobot, V.I., Mykhonik, L.A., Hryshchenko, A.M. (2017) Vplyv strukturoutvoryuvachiv na yakist' bezhlyutenovoho khliba iz sumishi rysovoho ta kukurudzyanoho boroshna [Influence of structurants on the quality of gluten-free bread from a mixture of rice and corn flour]. Naukovi pratsi Natsional'noho universytetu kharchovykh tekhnolohiy. Vol. 23. No. 6. pp. 169-175. [in Ukrainian]

8. Khrystenko, A.S. (2020). Khlibobulochi vyroby z ponyzhenym vmistom alerheniv [Bakery products with low allergen content]. Visnyk students 'koho naukovoho tovarystva "VATRA" Vinnyts'koho torhovelno-ekonomichnoho instytutu KNTEU. Vol. 98. pp. 137-145. [in Ukrainian]

9. Alvarez-Jubete L., Arendt E.K., Gallagher E. (2010) Nutritive value of pseudocereals and their increasing use as functional gluten-free ingredients Trends in Food Science \& Technology. Vol. 21. Issue 2. pp. 106-113. [in Ireland]

10. Xu, J., Zhang, Y., Wang, W., Li, Y. (2020) Advanced properties of gluten-free cookies, cakes, and crackers: A review. Trends in Food Science \& Technology. Vol. 103. pp. 200-213. [in English]

11. Rai, S., Kaur, A., Chopra, C.S. (2018) Gluten-free products for celiac susceptible people. Frontiers in nutrition. Vol. 5, pp. 116. [in Indian]

12. Martínez-Villaluenga C., Peñas E., Hernández-Ledesma B. (2020) Pseudocereal grains: Nutritional value, health benefits and current applications for the development of gluten-free foods. Food and Chemical Toxicology. Vol. 137. P. 111-178. DOI: 10.1016/j.fct.2020.111178. [in Spain]

13. Dzyundzya, O.V., Zvagolska, K.V. (2021) Analiz netradytsiynoyi boroshnyanoyi syrovyny dlya vyrobnytstva khlibobulochnykh vyrobiv [Analysis of non-traditional flour raw materials for the production of bakery products] Tavriys 'kyy naukovyy visnyk. Seriya: Tekhnichni nauk. No. 1, pp. 22-29. DOI: 10.32851/tnv-tech.2021.1.4. [in Ukrainian] 